\title{
ANALISIS ANGGARAN BIAYA OPERASIONAL DAN ANGGARAN PENDAPATAN TERHADAP KINERJA KEUANGAN BERDASARKAN RETURN ON ASSET (ROA) PADA PT MADUBARU YOGYAKARTA TAHUN 2012-2016
}

\author{
Sigit Aryatama \\ sigitaryatama@gmail.com \\ Universitas Ahmad Dahlan \\ Deny Ismanto \\ denoxis@yahoo.com \\ Universitas Ahmad Dahlan
}

\begin{abstract}
ABSTRAK
This study aims to determine the presence or absence of influence operational cost budget and revenue budget to financial performance based on return on assets (ROA) at PT Madubaru Yogyakarta in the year 2012-2016. In this study there are three variables, namely budget operational (X1), revenue budget (X2), and ROA (Y). Research methods what I use is the quantitative analysis method, the type of data it uses secondary data, data collection techniques used are documentation and Interview. Data analysis techniques using multiple linear regression with SPSS program version 20. The results showed that the budget Operational and income budgets affect return on assets (ROA) seen with an R value of 0.962 . Partially operational budget has no effect on ROA and income budget has an effect on ROA.
\end{abstract}

Keywords: Operational Budget; Income Budget; Return On Asset (ROA)

\begin{tabular}{l}
\hline \multicolumn{3}{c}{ PENDAHULUAN } \\
\cline { 2 - 2 } Setiap perusahaan berupaya \\
semaksimal mungkin untuk mencapai \\
tujuan yang telah mereka rencanakan. \\
Untuk mencapai tujuan tersebut, maka \\
setiap perusahaan senantiasa berusaha \\
untuk meningkatkan efisiensi maupun \\
efektifitas kerja perusahaan. Salah satu \\
elemen penting perencanaan dan \\
pengendalian perusahaan adalah anggaran. \\
Anggaran oleh banyak perusahanaan \\
diyakini dapat meningkatkan kinerja \\
perusahaan. Anggaran merupakan suatu \\
rencana terperinci untuk dimasa yang akan \\
datang dan dinyatakan dalam ukuran \\
kuantitatif. Kegiatan bidang ini sangat erat \\
hubungannya, baik dalam tahap
\end{tabular}

penyusunan hingga tahap pelaksanaan dan realisasi anggaran.

Semakin komplek suatu masalah dalam perusahaan dilakukan berdasarkan perencanaan yang tepat dan cermat. Oleh karena itu, peranan anggaran bagi perusahaan sangatlah penting sebagai bentuk awal perencanaan perusahaan dimana tidak hanya dianggap sebagai penunjang kegiatan operasional perusahaan saja tetapi digunakan juga sebagai tolak ukur dalam mencapai keberhasilan usaha usaha yang telah digariskan sebelumnya.

Anggaran adalah rencana tertulis mengenai kegiatan organisasi yang dinyatakan secara kuantitatif untuk jangka waktu tertentu dan umumnya dinyatakan dalam satuan uang, tetapi dapat juga dinyatakan dalam satuan barang.

Secara garis besar anggaran merupakan alat manajemen untuk 
mencapai tujuan. Sehingga dalam proses penyusunan dibutuhkan data dan informasi, baik yang bersifat terkendali maupun yang bersifat tak terkendali untuk dijadikan bahan taksiran. Hal ini disebabkan karena data dan informasi tersebut akan berpengaruh terhadap keakuratan taksiran dalam proses perencanaan anggaran.

Apabila perencanaan anggaran tidak tercapai, secara teoritis dapat dikatakan bahwa kinerja (keuangan) perusahaan akan berpengaruh. Hal tersebut disebabkan karena pendapatan, beban, persediaan, kas, modal ataupun asset lainnya berbeda dari perencanaan yang diformulasikan melalui rancangan anggaran.

\section{Rumusan Masalah}

1. Apakah anggaran biaya operasional berpengaruh terhadap rasio return on asset (ROA) pada PT Madubaru Yogyakarta?

2. Apakah anggaran pendapatan berpengaruh terhadap kinerja keuangan berdasarkan rasio return on asset (ROA) pada PT Madubaru Yogyakarta?

3. Apakah anggaran biaya operasional dan anggaran pendapatan berpengaruh terhadap rasio return on asset (ROA) pada PT Madubaru Yogyakarta?

\section{REVIEW LITERATUR DAN HIPOTESIS}

\section{Landasan Teori Anggaran}

Pengertian Anggaran Anggaran menurut Rudianto (2009) menyatakan bahwa "Anggaran adalah rencana kerja organisasi di masa mendatang yang diwujudkan dalam bentuk kuantitatif , formal, dan sistematis". Anggaran menurut Sasongko et all (2010:2) menyatakan bahwa“Anggaran adalah Rencana kegiatan yang akan dijalankan oleh manajemen dalam satu periode yang terulang secara kuantitatif".

\section{Rasio Keuangan}

Rasio Keuangan Dalam mengevaluasi kondisi keuangan perusahaan dan kinerjanya, analis keuangan perlu melakukan pemeriksaan atas berbagai aspek kesehatan keuangan perusahaan. Dengan menggunakan alat analisis laporan keuangan, terutama bagi pemilik usaha dan manajemen, dapat diketahui berbagai hal yang berkaitan dengan keuangan dan kemajuan perusahaan. Alat yang sering digunakan selama pemeriksaan adalah rasio keuangan.

$$
\text { Return on Asset (ROA) }
$$

Return on Asset (ROA) merupakan rasio yang menunjukkan hasil (return) atas jumlah aktiva yang digunakan dalam perusahaan. Rumus untuk mencari pengembalian atas aset (ROA) dapat digunakan sebagai berikut:

$$
\text { ROA }=\frac{\text { Laba setelah Bunga dan Pajak }}{\text { Total Aktiva }}
$$

\section{Anggaran Biaya Operasional}

Anggaran biaya operasional adalah anggaran atau taksiran semua biaya yang dikeluarkan oleh perusahaan selama kegiatan operasi perusahaan dalam jangka waktu satu tahun periode akuntansi. Penyusunan anggaran biaya operasional yang lazim terjadi pada suatu perusahaan adalah mencakup anggaran berikut:

\section{Penelitian Terdahulu}

Sebagai bahan pertimbangan dalam penelitian ini akan dicantumkan beberapa hasil penelitian terdahulu oleh beberapa peneliti, diantaranya : Hasil penelitian yang sudah dilakukan oleh Sukma et all (2011) dengan judul "Analisis Anggaran Biaya Operasional dan Anggaran Pendapatan terhadap Kinerja Keuangan Berdasarkan Return On Asset (ROA) pada PT Graha Sarana Duta Palembang” 
diketahui bahwa anggaran biaya operasional dan anggaran pendapatan tidak berpengaruh terhadap ROA. Dengan variabel Anggara Biaya Operasional (X1), Anggaran Pendapatan (X2) dan ROA (Y) Hasil penelitian yang sudah dilakukan oleh Christie (2009) dengan judul "Peran Partisipasi Anggaran, Tingkat Kesulitan Anggaran dan Evaluasi Anggaran Terhadap Kinerja Manajerial Pada PT PLN (Persero) Area Pelayanan dan Jaringan Surabaya Selatan" diketahui bahwa partisipasi anggaran, tingkat kesulitan anggaran dan evaluasi anggaran berpengaruh terhadap kinerja manajerial berpengaruh positif. Dengan variabel Partisipasi anggaran (X1), Tingkat kesulitan anggaran (X2) dan Evaluasi anggaran (X3) serta Kinerja manajerial (Y) Hasil penelitian yang sudah dilakukan oleh Agustin et all (2013) dengan judul "Pengaruh Anggaran Biaya Operasional Terhadap Kinerja Keuangan Perusahaan Pada PT Muara Dua Palembang" diketahui bahwa Anggaran Biaya Operasional berpengaruh signifikan terhadap Kinerja. Dengan Variabel Anggaran Biaya Operasional (X) dan Kinerja Keuangan (Y).

\section{Hipotesis}

H1: Anggaran biaya operasional berpengaruh negatif terhadap kinerja keuangan berdasarkan rasio return on asset (ROA) pada PT Madubaru Yogyakarta.

$\mathrm{H} 2$ : Anggaran pendapatan berpengaruh positif terhadap kinerja keuangan berdasarkan rasio return on asset (ROA) pada PT Madubaru Yogyakarta.

H3: Anggaran biaya operasional dan anggaran pendapatan berpengaruh terhadap kinerja keuangan berdasarkan rasio return on asset (ROA) pada PT Madubaru Yogyakarta.

\section{METODE PENELITIAN}

\section{Populasi dan Sampel}

Populasi dalam penelitian ini adalah Laporan Keuangan PT. MAdubaru Yogyakrta. Sampel dalam penelitian ini adalah PT. Madubaru Yogyakarta.

\section{Definisi Operasional}

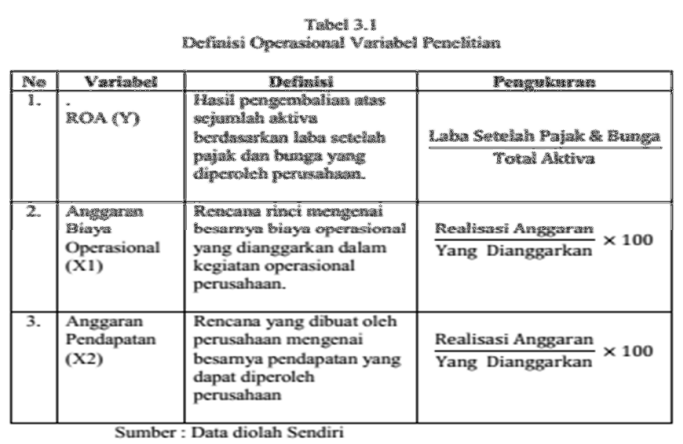

\section{Teknik Analisis Data}

Analisis data mempunyai tujuan untuk menyampaikan dan membatasi penemuan hingga menjadi data yang teratur dan lebih berarti. Analisis data yang digunakan pada penelitian ini adalah analisis kuantitatif yang dinyatakan dengan angka-angka yang diolah menggunakan program SPSS.

\section{Analisis Regresi Linier Berganda}

Regresi linier berganda merupakan model yang akan menjelaskan pengaruh variabel independen secara bersama-sama (simultan) terhadap variabel dependen. Bentuk persamaan regresinya adalah sebagai berikut:

$$
\mathbf{Y}=\mathbf{a}+\mathbf{b}_{1} \mathbf{X}_{1}+\mathbf{b}_{2} \mathbf{X}_{2}+e
$$

\section{Uji Hipotesis}

1. Uji Parsial (Uji T)

Uji t pada dasarnya menunjukkan seberapa jauh pengaruh satu variabel penjelas/independen secara individual dalam menerangkan variasi variabel 
dependen. Pengambilan keputusan penelitian ini diperoleh dengan cara membandingkan t-statistik masing masing variabel independen dengan $\mathrm{t}$ tabel (one-tail) pada tingkat alpha yang ditentukan. Apabila t-statistik lebih besar dari t-tabel (one tail) dengan arah yang sesuai maka hipotesis alternatif diterima yang artinya variabel independen tersebut berpengaruh secar signifikan terhadap variabel dependennya, dan begitu pula sebaliknya.

2. Uji Koefisien Determinasi

Uji $\mathrm{R}_{2}$ digunakan untuk menguji seberapa besar kemampuan model dalam menerangkan variasi variabel dependen. Nilai koefisien determinasi adalah antar nol sampai satu $\left(0<\mathrm{R}^{2}<1\right)$. Nilai $\mathrm{R}^{2}$ yang kecil berarti kemampuan variabel - variabel independen dalam menjelaskan variasi variabel dependen amat terbatas. Nilai yang mendekati satu berarti variabel-variabel independen memberikan hampir semua informasi yang dibutuhkan untuk memprediksi variasi variabel dependen (Ghozali, 2006).

\section{HASIL PENELITIAN DAN PEMBAHASAN}

\section{Analisis Regresi Linier Berganda}

Analisis Linear Berganda

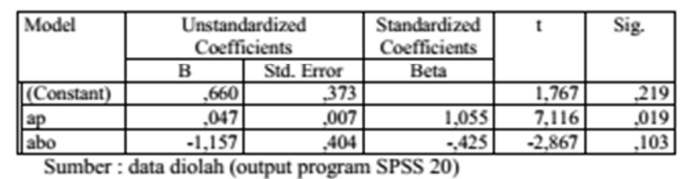

Berdasarkan data di atas, persamaan regresinya sebagai berikut:

$\mathrm{Y}=\mathrm{a}+\mathrm{b}_{1} \mathrm{X}_{1}+\mathrm{b}_{2} \mathrm{X}_{2}$

$\mathrm{Y}=0.660+0,047 \mathrm{X}_{1}-1,157 \mathrm{X}_{2}$

Persamaan regresi di atas dapat dijelaskan sebagai berikut: Konstanta sebesar 0,660, artinya apabila Anggaran Pendapatan (X1) dan Anggaran Biaya
Operasional $\left(\mathrm{X}_{2}\right)$ nilainya 0 , maka nilai ROA-nya adalah 0,660. Koefisien regresi variabel Anggaran Pendapatan (X1) sebesar 0.047, artinya apabila Anggaran Pendapatan (X1) dinaikkan 1\%, maka nilai ROA akan mengalami peningkatan sebesar 0.047 dengan asumsi bahwa variabel independen lain nilainya tetap. Koefisien regresi variabel Biaya Operasional $\left(\mathrm{X}_{2}\right)$ sebesar -1,157, artinya apabila Biaya Operasional $\left(\mathrm{X}_{2}\right)$ mengalami kenaikan $1 \%$, maka nilai ROA akan mengalami penurunan sebesar -1,157 dengan asumsi variabel independen lain nilainya konstan.

\section{Uji Hipotesis}

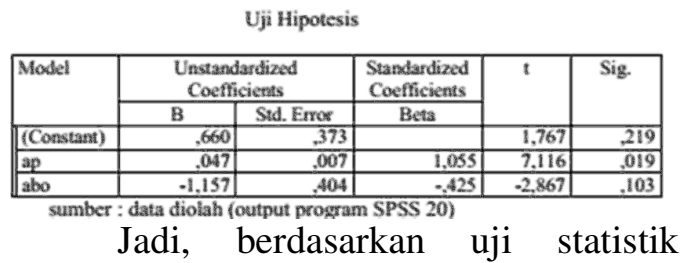
dengan pengujian $t$, maka Ho diterima. Sehingga dapat disimpulkan bahwa anggaran biaya operasional secara parsial tidak berpengaruh signifikan terhadap ROA.

Secara statistik dikatakan, anggaran biaya operasional tidak berpengaruh terhadap kinerja keuangan. Namun, secara teori diungkapkan bahwa biaya merupakan akun pengurang aktiva dalam suatu perusahaan. Artinya semakin besar biaya, maka seakin besar pengurangan terhadap aktiva perusahaan khususnya akun kas.

Data yang terdapat pada tabel 5.2 menyajikan informasi tentang kondisi realisasi anggaran biaya operasional pada tahun 2014 lebih kecil dari target. Maka biaya yang dikeluarkan oleh perusahaan lebih kecil. Sehingga pengurangan terhadap aktiva juga lebih kecil. Dalam teori dijelaskan, ROA diperoleh dari perbandingan antara laba dan total aktiva. Biaya operasional yang lebih kecil dari target akan mengurangi aktiva lebih kecil. Di sisi lain dijelaskan pula bahwa biaya operasional yang kecil akan 
mengurangi pendapatan perusahaan lebih kecil sehingga laba perusahaan akan lebih besar. Akan tetapi, rasio return on asset yang ditampilkan pada tabel 5.3 mengimplikasikan bahwa penambahan aset yang tidak diimbangi oleh peningkatan laba menyebabkan nilai ROA semakin kecil. Sehingga dapat dikatakan bahwa fluktuasi biaya operasional tidak memiliki pengaruh terhadap nilai ROA apabila total aset perusahaan lebih besar sedangkan peningkatan laba tidak signifikan.

Oleh karena itu, hasil statistik yang menyatakan biaya operasional tidak memiliki pengaruh signifikan terhadap nilai ROA dapat diterima, dengan asumsi penambahan aset perusahaan tidak diimbangi oleh peningkatan laba operasi perusahaan

Jadi, berdasarkan uji statistik secara parsial, dengan memperhatikan perbandingan $t$ hitung yang lebih besar dari $t$ tabel dan tingkat signifikansi yang lebih kecil yakni 1,9\% dari standar signifikansi sebesar 5\%, maka dapat disimpulkan bahwa $\mathrm{Ha}$ diterima atau anggaran pendapatan secara parsial berpengaruh signifikan terhadap ROA. Penjelasan secara teoritis, dikatakan semakin besar pendapatan sebuah perusahaan dan biaya operasionalnya semakin kecil, maka laba yang diperoleh perusahaan akan semakin besar. Laba yang besar juga berpengaruh besar terhadap kinerja keuangan termasuk rasio return on asset perusahaan, dan begitu pula sebaliknya.

Anggaran pendapatan yang tercantum pada tabel 5.1 mengimplikasikan bahwa pendapatan perusahaan mengalami fluktuatif. Begitupula dengan laba yang diperoleh perusahaan, Sehingga kinerja keuangan perusahaan tidak maksimal, hal ini dibuktikan pada tabel 5.3 yang mengalami penurunan pada setiap tahunnya. Artinya anggaran pendapatan perusahaan memiliki pengaruh terhadap kinerja keuangan termasuk rasio return on asset (ROA).

\section{Uji F (Simultan)}

\begin{tabular}{|l|r|r|r|r|r|}
\hline \multicolumn{1}{|c|}{ Model } & Sum of Squares & df & Mean Square & F & Sig. \\
\hline Regression &, 009 & 2 &, 005 & 25,347 &, $038^{\circ}$ \\
\hline Residual &, 000 & 2 &, 000 & & \\
\hline Total &, 009 & 4 & & & \\
\hline
\end{tabular}

biaya operasional perusahaan akan memberikan informasi, apakah perusahan mengalami kerugian atau mengalami keuntungan. kerugian atau keuntungan dari perhitungan antara pendapatan dan biaya operasional akan berpengaruh terhadap kinerja keuangan perusahaan, termasuk rasio profitabilitas yang didalamnya terdapat rasio return on asset (ROA).

Berdasarkan pengujian statistik dengan metode uji F, di mana tingkat signifikansi yang diperoleh lebih Besar yakni sebesar 3,8\% dari standar signifikansi yakni $5 \%$ atau 0,05 dan perbandingan antara $\mathrm{F}$ hitung dan $\mathrm{F}$ tabel, di mana $\mathrm{F}$ hitung sebesar 25,347 lebih besar dari $\mathrm{F}$ tabel yakni 19.00, maka dapat disimpulkan bahwa $\mathrm{Ha}$ diterima atau anggaran biaya operasional dan anggaran pendapatan memiliki pengaruh yang signifikan terhadap ROA.

Jadi dapat disimpulkan bahwa berdasarkan hasil statistik penelitian uji F,anggaran biaya operasional dan anggaran pendapatan memiliki pengaruh yang signifikan terhadap kinerja keuangan, khususnya rasio return on asset (ROA)

\section{Uji Koefisien Determinasi $\left(R^{2}\right)$}

Koefisien Determinasi

\begin{tabular}{|l|c|r|r|r|c|}
\hline Model & R & R Square & $\begin{array}{c}\text { Adjusted R } \\
\text { Square }\end{array}$ & $\begin{array}{c}\text { Std. Error of } \\
\text { the Estimate }\end{array}$ & $\begin{array}{c}\text { Durbin- } \\
\text { Watson }\end{array}$ \\
\hline 1 & $.981^{2}$ & 962 & .924 &, 01341 & 2,800 \\
\hline
\end{tabular}

Jadi dapat disimpulkan bahwa berdasarkan teori dan hasil statistik penelitian berdasarkan koefisien determinasi, anggaran biaya operasional dan anggaran pendapatan memiliki hubungan yang erat terhadap rasio return on asset. 


\section{KESIMPULAN DAN SARAN}

\section{Kesimpulan}

1. Credit Risk (NPL) secara parsial Berdasarkan pengujian $\mathrm{t}$ statistik disimpulkan bahwa secara parsial anggaran biaya operasional tidak berpengaruh terhadap Return on Asset (ROA). Sedangkan, anggaran pendapatan berpengaruh terhadap Return on Asset (ROA).

2. Pengujian hipotesis dengan menggunakan uji $\mathrm{F}$ statistik menyimpulkan bahwa anggaran biaya operasional dan anggaran pendapatan memiliki pengaruh yang signifikan terhadap Return on Asset (ROA)

3. Berdasarkan nilai koefisien determinasinya, anggaran biaya operasional dan anggaran pendapatan memiliki hubungan yang erat terhadap Return on Asset (ROA) dengan nilai $\mathrm{R}$ square sebesar 0,962 .

\section{Saran}

1. Baik perusahaan maupun penelitian selanjutnya sebaiknya

mempertimbangkan kemungkinan pengaruh variabel lain yang digunakan dalam mengukur pengaruhnya terhadap ROA, misalnya anggaran beban administrasi dan umum serta anggaran biaya penjualan.

2. Perusahaan sebaiknya memerhatikan penyusunan dan penetapan anggaran biaya operasional dan anggaran pendapatan agar memberikan kontribusi yang lebih baik dalam penilaian kinerja perusahaan.

3. Perusahaan sebaiknya mempertimbangkan perbandingan yang proporsional antara peningkatan aktiva dan perolehan laba rugi perusahaan yang berpengaruh besar terhadap penilaian kinerja keuangan, khususnya Return on Asset (ROA

\section{DAFTAR PUSTAKA}

Agustin, Nyayu Nanda Tiara, et all. 2013.’Pengaruh Anggaran Biaya Operasional Terhadap Kinerja Keuangan Perusahaan pada PT Muara Dua Palembang" Jurnal Ekonomi dan Bisnis Indonesia. Catur Sasongko, et all 2010. Anggaran. Jakarta . Salemba empat.

Christie, Graffiratna. 2009.’Peran Partisipasi Anggaran, Tingkat Kesulitan Anggaran dan Evaluasi Anggaran Terhadap Kinerja Manajerial pada PT PLN (Persero) Area Jaringan Surabaya Selatan" EJurnal Akutansi.

Devi, Shinta Sukma, et all. 2011."Analisis Anggaran Biaya Operasional dan Anggaran Pendapatan Terhadap Kinerja Keuangan Berdasarkan Return On Asset (ROA) Pada PT Graha Sarana Duta Palembang" Jurnal Ekonomi dan Bisnis Indonesia.

Ghozali, Imam. 2011. Aplikasi Analisis Multivariate Dengan Program SPSS. Semarang. Universitas Diponegoro Kasmir. 2010. Analisis Laporan Keuangan. Jakarta. Rajawali Pers.

Munandar, M. 2007. Budgeting: Perencanaan Pengkoordinasian dan Pengawasan Kerja. Edisi kedua. Yogyakarta. BPFE-Yogyakarta. Nafarin, M. 2009. Penganggaran Perusahaan. Edisi ketiga. Jakarta. Salemba Empat.

Raharjo, Budi. 2003. Laporan Keuangan Perusahaan. Yogyakarta. 
Universitas Gadjah Mada Press.

Sugiyono. 2012. Memahami Penelitian

Kualitatif. Bandung. Alfabeta.

Van Horne, James C, et all. 2009.

Prinsip-prinsip Manajemen

Keuangan. Edisi keduabelas buku 1.

Jakarta. Salemba Empat. 